\title{
The Cretaceous spore Stoverisporites and its taxonomy and stratigraphy
}

\author{
${ }^{1}$ CHARLES FELIX \& ${ }^{2}$ PATRICIA BURBRIDGE \\ ${ }^{1}$ Department of Geology, Abilene Christian University, Abilene, Texas, USA, 79699 \\ ${ }^{2} 403$ Arborcrest, Richardson, Texas, USA, 75080
}

\begin{abstract}
The Cretaceous palynomorph commonly designated Kuylisporites lunaris is correctly identified taxonomically as Stoverisporites lunaris, while Kuylisporties should apply to "Hemitelia type" spores. Stoverisporites lunaris is a useful stratigraphic indicator of Aptian - Albian sediments in the Canadian Arctic.
\end{abstract}

\section{INTRODUCTION}

In investigations of Arctic microfloras, it has been expedient to locate entities with stratigraphic utility that might prove valuable as zonal markers. These are often of limited geographical distribution or quantitatively scarce, but still of sufficient abundance to be valuable zonal tools. An example of such an entity, but with questionable taxonomy, is the spore Stoverisporites lunaris (Cookson \& Dettmann) Burger, 1975. Cited frequently in palynological literature as Kuylisporites lunaris, it is an example of confused taxonomy, with both generic and specific assignments being questionable. We have recorded it in a wide range of study areas, both in the Canadian Archipelago and the Mackenzie District of northern Canada (Fig. 1). Other investigators active in these areas have also noted it in both surface and subsurface, often in considerable numbers. Geographically it is widespread with reported occurrences also in Australia, South American, and numerous records in the USSR. S. lunaris is a species of short stratigraphic distribution in the Arctic, and it has value as a palynology zonal marker. Doerenkamp et al. (1976) did a comprehensive Arctic palynology study and established a number of palynomorph zones, which they considered of significance in stratigraphic studies. Their palynomorph zones included six Cretaceous and two Tertiary, with their work being ecological and stratigraphic in scope and limited to CretaceousTertiary assemblages primarily on Banks Island and adjacent Arctic areas.

\section{TAXONOMY}

The spore is also an entity whose nomenclature has been emended by Burger (1975) but is still unknown or ignored by most recent investigators in their recording its presence in Cretaceous age rocks. Burger (1975) considered the taxon described as Kuylisporites lunaris to be more appropriately assigned to the genus Stoverisporites. In doing so it would appear that he considered Kuylisporites (sensu Potonié) the proper repository for Hemitelia type spores, but with morphologically dissimilar spores as represented by $K$. lunaris more properly assigned to the genus Stoverisporites.

The genus Kuylisporites was originally established by Potonié (1956) for a lower Tertiary spore with Kuylisporites waterbolki being designated the genotype. The type had previously been recognised by Kuyl et al. (1955) but not validly described and was referred to only as Hemitelia type. However, Krutzsch (1959) considered Kuylisporites being best typified by $K$. mirabilis (Bolkhovitina) Potonié, 1958, an opinion later rejected by Dettmann (1963, p. 39). These assignments all referred to a spore characterised by three oval depressions on the proximal surface, each depression being situated half the distance between the spore angles. It does display a distinct resemblance to extant Cyatheaceae. Muller (1959, pl. 1, fig. 5) figured such a configuration for Hemitelia, and Selling (1946) described similar depressions for Cibotium.

Other workers were also preoccupied with a possible affinity with the extant fern Hemitelia of the Cyatheaceae. Among these were Chlonova (1961, pl. 2, fig. 13) and Kuyl et al. (1955, pl. 1, fig. 7). Admittedly the spore's morphology is suggestive of Hemitelia, but superficial comparisons to extant pteridophyta are commonplace in the fossil record, and it would appear that this implied relationship is the basis for the subsequent transfer of Hemitelia mirabilis to Kuylisporites by Potonié (1958). Chlonova (1961) recorded Hemitelia separata, which Dettmann (1963) included in Kuylisporites. Such implied relationships to extant Cyatheaceae must be suspect, for despite morphological similarities, the genotype of Hemitelia is lower Tertiary in age and a Cretaceous age has been assigned to most specimens attributed to Kuylisporites. However, there is admittedly a definite morphological similarity between fossil and extant Hemitelia. Also, Hemitelia is by no means restricted to the Tertiary as Komarova (1973) figured it in the Cretaceous of the Turgay Plain. 


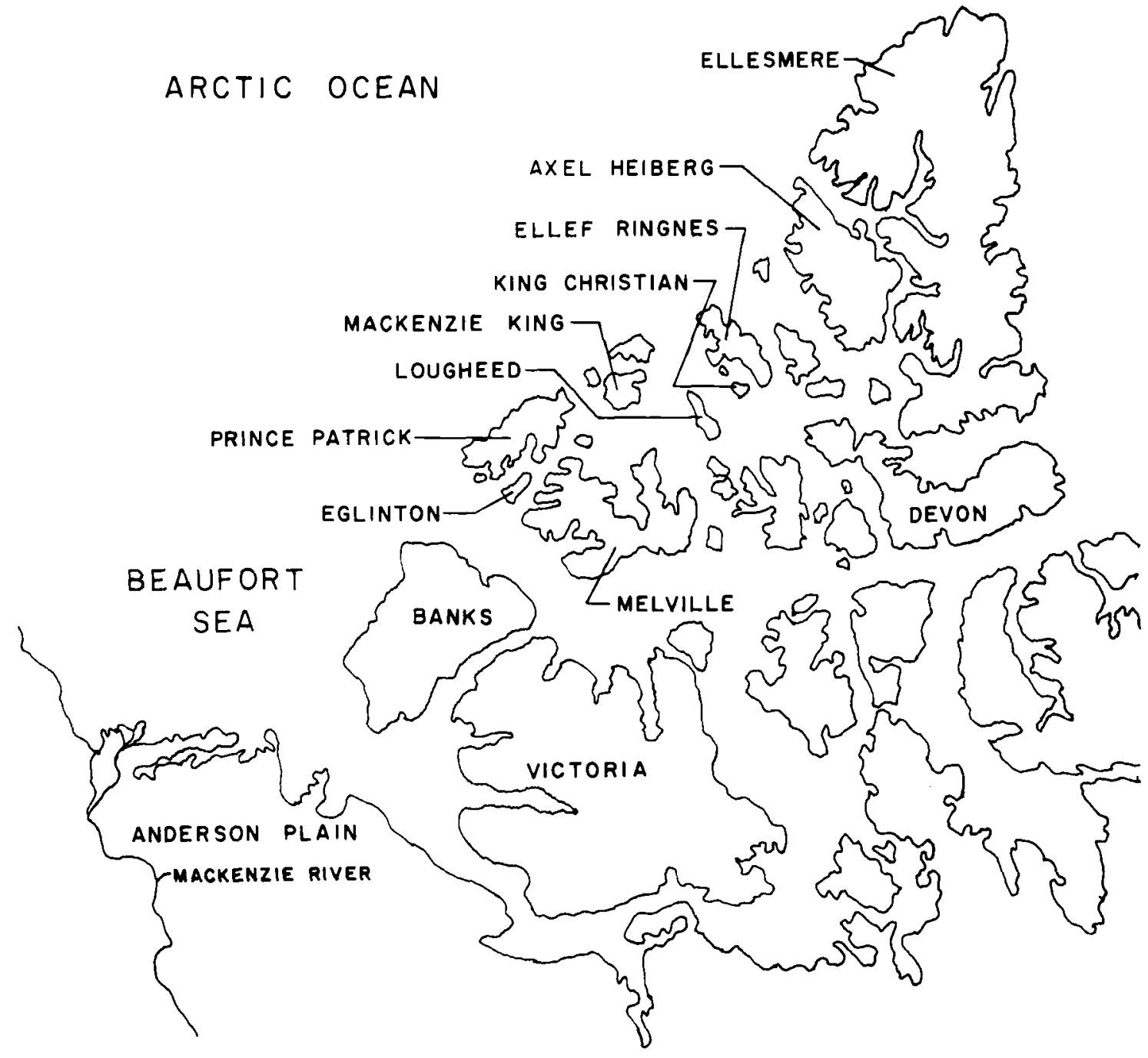

Fig. 1. Map of the Canadian Arctic islands covered in this study.

It appears that it was the intention of Burger (1975) to differentiate from the Hemitelia type with the three oval depressions located mid-way between the radial positions and permit Kuylisporites to represent such a taxon. Inasmuch as the original diagnosis referred to this Hemitelia type, a separate designation for forms with shallow pits on the spore surface is justified. Therefore, Kuylisporites should include only those specimens of Cyatheaceae characters with the three depressions between the radial positions. Accordingly, those entities with the numerous, scattered exinal pits and not of the Hemitelia type deserve separate taxonomic rank and Stoverisporites provides such a repository. The designation of $S$. microverrucatus as the type species of Stoverisporites might be questioned, and we would have suggested $K$. lunaris as a more appropriate specific epithet for the genotype. However. Burger's (1975) assignment of the type is taxonomically correct and acceptable.
It would appear that only Kemp \& Harris (1977) have recognised the legitimacy of Stoverisporites and of $S$. microverrucatus as the type. However, they did not encounter $S$. lunaris in their studies, which were Tertiary.

\section{PALYNOMORPH MORPHOLOGY}

The taxon which Cookson \& Dettmann (1958) established as Kuylisporites lunaris has a diagnostic feature of prominent ridges or elevations, which enclosed shallow lumina. These are the "scutula" of Potonie (1956), and they are referred to as crescenticshaped due to their elliptical outline in most instances. The crescent-shaped scutula are distinctly different from the oval depressions of Hemitelia. Dettmann (1963) also referred to the scutula as crescentic-shaped and partially enclosing shallow lumina in $K$. lunaris. In their description of the holotype of $K$. lunaris Cookson 
\& Dettmann (1958) described the scutula as half-moon shaped, However, their illustrations clearly depicted some completely circular scutula on the polar surface, with crescent-shaped thickenings situated marginally. They also noted the half-moon shaped scutula as occurring on both the proximal and distal surfaces in the holotype description. However, Dettmann (1963) in the description of $K$. lunaris from the Neocomian of Australia; noted the scutula as confined to the distal surface. The illustrations of $K$. lunaris by Brideaux \& McIntyre (1975) showed eight crescentic scutula on the distal surface and apparently none proximally. However, Shakhmoundes (1971) figured K. lunaris with six entire circular pits and reported all on the proximal surface. Although these various reports exist of scutula on the proximal surface, most investigators have noted them only on the spore's distal surface. Of the hundreds of specimens observed in this study, all have had the scutula restricted to the distal surface. It would appear that the reported proximal occurrences are the result of misinterpretation.

Although considerable morphological variation exists, especially as regard the type and number of the distal scutula, these differences seem insufficient for delineation of additional species. Numerically, a wide range occurs in our material from rare to numerous scutula, and varying combinations of hemi or circular scutula. Some spores bear only hemi-, others both forms; however, no entity displayed only circular scutula without hemi- being represented. Even the distribution of the scutula on the distal surface is inconsistent. They may have a peripheral orientation, with or without the depression in the mid-spore body, along with varying occurrences of hemi- or circular scutula peripherally or on the midbody.

The only instance of possible new speciation was a form differentiated by the scutula, which were uniformly oval in shape (Pl. 1, fig. 4) and without circular or hemi- scutula being present. In all other aspects it compared closely with $S$. lunaris. This variant did not display any stratigraphic utility, being observed in surface samples of Hassel Formation from Ellef Ringnes Island and Isachsen Formation from Melville Island. These samples contained numerous populations of spores with circular and hemi- scutula. The variant was rare, only five specimens having been observed during this study, and this is considered insufficient material to justify a new species.

\section{SYSTEMATICS}

Genus Stoverisporites Burger, 1975

Type Species: Stoverisporites microverrucatus Burger, 1975

Stoverisporites lunaris (Cookson \& Dettmann) Burger 1975

(PI. 1, figs. 1-6)

1958 Kuylisporites lunaris Cookson \& Dettmann; 103 , pl. 14, figs. 21-23.

1963 Kuylisporites lunaris Cookson \& Dettmann; Dettmann: 39-40, pl. 5, figs. 9-12.

1969 Kuylisporites lunaris Cookson \& Dettmann; Chlonova: 56 , pl. 10, figs. 2-3.

1970 Kuylisporites lunaris Cookson \& Dettmann; Kemp: 87 , pl. 11, figs. 5-8.

1971 Kuylisporites lunaris Cockson \& Dettmann; Playford: 539, pl. 103, fig. 3.

1971 Kuylisporites lunaris (Cookson \& Dettmann) Shakhmoundes; Samoilovich: 165, pl. 2, fig. 8.

1973 Kuylisporites lunaris Cookson \& Dettmann; Bityutskaya, et. al.: pl. 11, fig. 18.

1974 Kuylisporites lunaris Cookson \& Dettmann; Chlonova: 54, pl. 3, fig. 3.

1974 Kuylisporites lunaris Cookson \& Dettmann; Hopkins: 12, pl. 2, fig. 21.

1975 Kuylisporites lunaris Cookson \& Dettmann; Brideaux \& McIntyre: 14, pl. 1, fig. 16.

1975 Stoverisporites lunaris (Cookson \& Dettmann) Burger: 118-119, pl. 19, fig. 2.

1981 Kuylisporites lunaris Cookson \& Dettmann: Herngreen \& Chlonova: 460, pl. 4, fig. 4.

Genus Kuylisporites Potonié, 1956

Type Species: Kuylisporites waterbolki Potonié, 1956

1955 Cyatheaceae (Hemitelia type) Kuyl, Muller \& Waterbolk: 62, pl. 1, fig. 7.

1959 Hemitelia sp. Muller: 16, pl. 1, fig. 5.

1973 Kuylisporites waterbolki Potonié; Stover \& Evans: 68, pl. 3, fig. 13.

\section{COLLECTING LOCALITIES}

The palynomorph is widespread and common in the Arctic sediments, but the major material for this study involved surface localities specifically collected by the senior author as reference standards for Arctic investigations. Four of these reference standards are listed (Table 1) with the geological formations in which Stoverisporites specimens were studied. A number of subsurface occurrences were a!so utilised, consisting of both well cuttings and core samples (Table 1).

\section{STRATIGRAPHY}

Three distinctive formations of Lower Cretaceous Rocks are of stratigraphic interest in the distribution of this spore. These are the Isachsen, Christopher, and Hassel Formations, Across the northern Arctic there is 


\section{SURFACE LOCALITIES}

Sun Section 17 Sabine Peninsula. Melville Island Sun Section 18 Central Ellef Ringnes Island

Sun Section 45 East Blacktop Ridge, Ellesmere Island.

Sun Section 80 Mackenzie King Island.

\section{SUBSURFACE LOCALITIES}

Well Cutting Sun Skybattle Bay C-15 Well. Lougheed Island.

Well Cutting Pan Arctic Sandy Point Well. Melville Island.

Well Cutting Dome Arctic Ventures Wallis K-62 Well. King Christian Island.

Well Cutting Shell Aklavik A-37 Well. Mackenzie Delta.

Well Cutting Gulf East Reindeer C-38 Well. Mackenzie Delta.

Seismic Core Elve Point Island.

Seismic Core Lougheed Island.

Core Sample Grosvenor Island.
Hassel,

Christopher,

Isachsen

Christopher

Isachsen

Hassel, Christopher, Isachsen

Christopher, Isachsen

Isachsen

Christopher

Christopher

Hassel,

Christopher

Hassel

Hassel

Fig. 2. Cretaceous stratigraphic nomenclature, Arctic Canada.

a wide variation in Cretaceous deposition based upon deposition, topography, erosion, and environment. Plauchut \& Jutard (1976) discussed the complexities of the stratigraphy and the difficulty in recognising equivalent facies. Although there will be variations in the Sverdrup Basin in the formations of interest, the spore Stoverisporites is likely restricted to the IsachsenChristopher-Hassel as depicted in Fig. 2.

Probably the most thorough palynological studies of the stratigraphic section in which $S$. lunaris occurs have been the investigations of Plauchut \& Jutard (1976) and Doerenkamp et al. (1976) in which they made comprehensive studies of the palynology of the Hassel, Christopher, and Isachsen formations on Banks and Eglinton Islands, as well as the Anderson Plain of the Canadian mainland. Although their microfloras compared remarkably well with those of our Sverdrup Basin studies in the same stratigraphic intervals, $S$. lunaris was not reported in any of their assemblages.

Eglinton Island is not strictly part of the Sverdrup Basin proper, but it seems reasonable to consider it since the island is a minor horst with a major graben stretching southward from Prince Patrick Island towards Banks Island, providing a link from the Sverdrup Basin to the Western Canadian Sedimentary Basin. During the Cretaceous, sediments overlapped the basin confines in the Eglinton Graben and Banks extension. In view of the geographic and stratigraphic extent of the studies by Plauchut \& Jutard (1976) and Doerenk- amp et al. (1976), the apparent absence of $S$. lunaris is somewhat unexpected. The spore could have simply been overlooked, inasmuch as it is a minor element quantitatively. However, it has been recorded often in the Mackenzie Delta and has a widespread occurrence in the giant Sverdrup Basin, and its absence here was unexpected.

Numerous references exist of $K$. lunaris being cited and not figured, but it is likely that one can assume that the entity cited is the spore featured by the hemiscutula (K. lunaris sensu Cookson \& Dettmann 1958). Burger (1973) recorded it from the Neocomian of the great Artesian Basin, Queensland. Archangelsky \& Gamerro (1967) referred to it in their Lower Cretaceous study in Patagonia. Robbins et al. (1975) noted it in their Cretaceous work on the Atlantic Coastal Plain.

The only significant reference of its occurrence in other than Cretaceous deposits is an assignment to Norwegian Jurassic rocks by Vigran \& Thusu (1975), Thusu \& Vigran (1976), and Birkelund et al. (1978). In these three instances they referred to Kuylisporites lunaris, and we assume their reference is to Stoverisporites lunaris. However, only Vigran \& Thusu (1975) illustrate the spore referred to (pl. 3, figs. 16-17), and it is clearly not $S$. lunaris. Accordingly, the other Norwegian assignments to the Jurassic are suspect, and a Cretaceous range only for the spore appears most likely. 

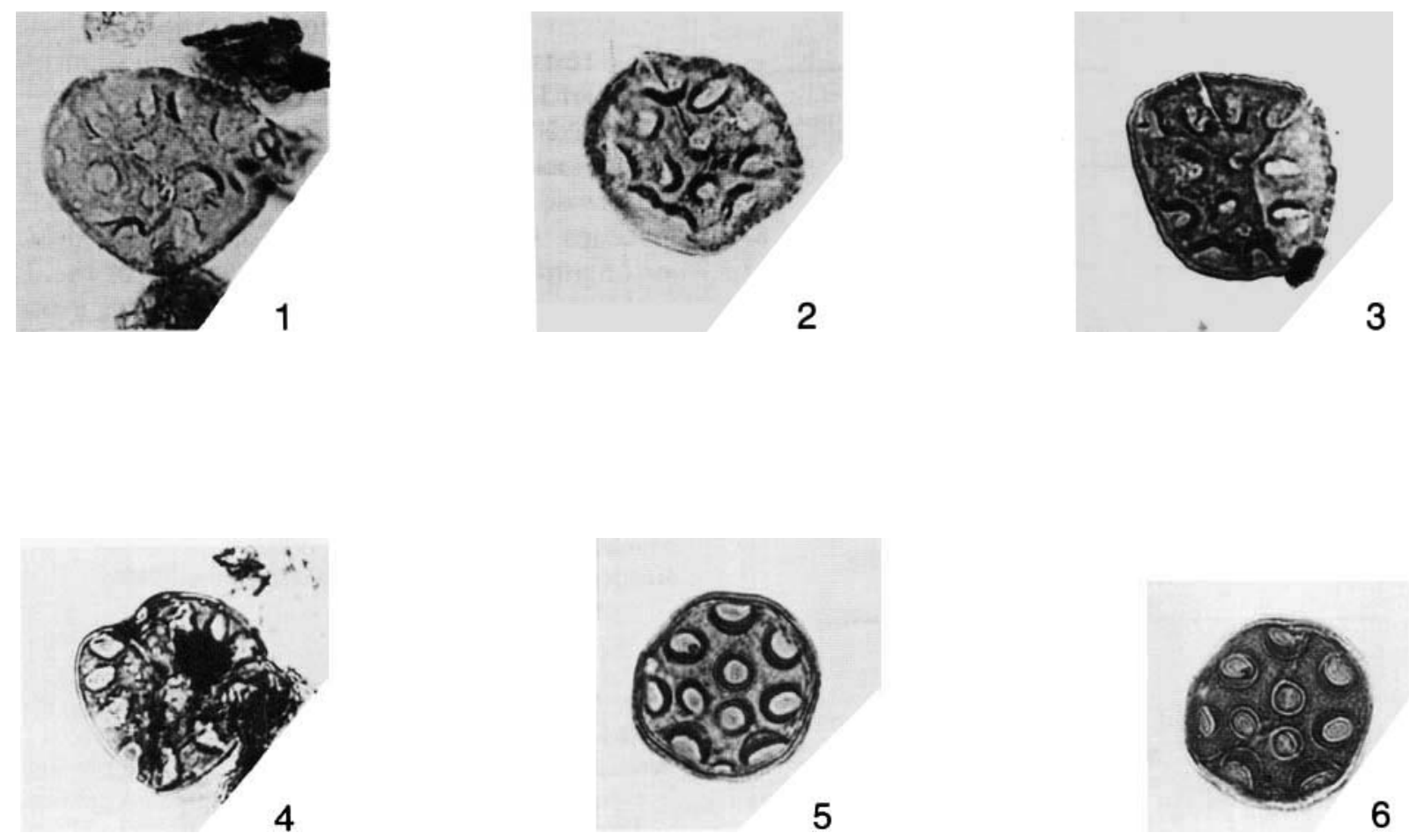

\section{Explanation of Plate 1}

Stoverisporites lunaris (Cookson \& Dettmann) Burger, 1975

All figures are $\times 500$.

Fig. 1. Christopher Formation. Surface Section 17. Melville Island. Slide 8136-1.

Fig. 2. Christopher Formation. Surface Section 18. Ellef Ringnes Island. Slide 7612-1.

Fig. 3. Isachsen Formation. Dome Arctic Ventures Wallis K-62 well. Well cuttings $1830-90 \mathrm{ft}$. King Christian Island. Slide 14660-1.

Fig. 4. Hassel Formation. Surface Section 18. Ellef Ringnes Island. Slide 7476-1.

Fig. 5. Specimen with focus on distal surface. Hassel Formation. Seismic Line 104, $85 \mathrm{ft}$. Lougheed Island. Slide 5138-1.

Fig. 6. Same specimen with focus on proximal surface. 
STAGE

FORMATION

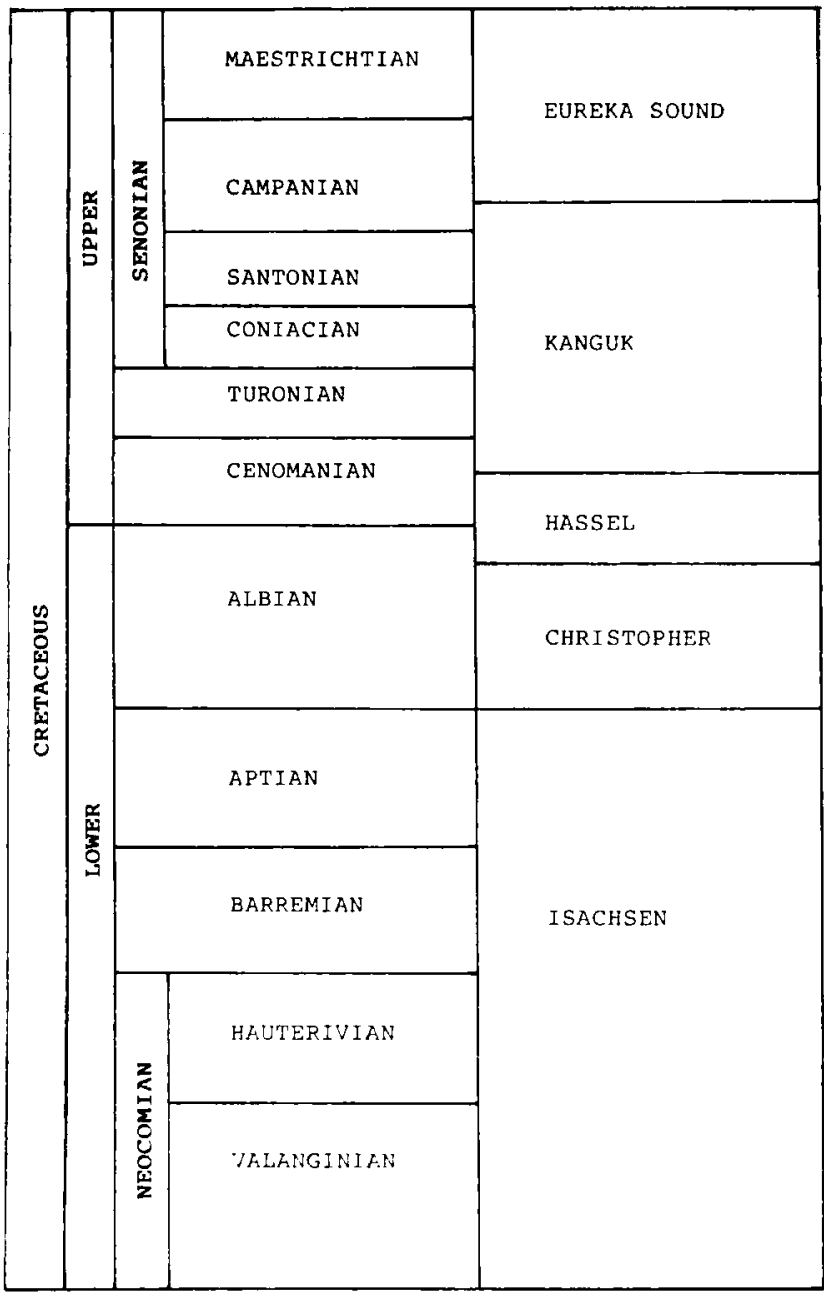

Fig. 2. Cretaceous stratigraphic nomenclature, Arctic Canada.

The total reported stratigraphic range for the taxon, exclusive of the Norweigian Jurassic occurrences, extends from the Hauterivian report of Shakhmoundes (1971) to a Cenomanian age for the Bathurst Island K3a Unit occurrences of Burger (1975). Burger (1973), Kemp (1976) and Dettmann (1963) had the lower limits in the Neocomian. However, it appears that the majority of assignments, especially in the northern hemisphere, suggest an Aptian-Albian range. In the Arctic area of interest, primarily the Sverdrup Basin, the taxon occurs in the three formations, again suggesting Aptian-Albian. However, only in the Christopher Formation is it abundant and extends through the entire formation. Its occurrence at present does also seem to extend into the lower Hassel and the upper Isachsen formations.

There are problem areas in identifying the formations of interest. The Christopher is a widespread sequence of marine shales in the Sverdrup Basin and of variable thickness. At various localities the Christopher shale rests conformably on the Isachsen sandstone, but on Ellef Ringnes Island a transition zone some $350 \mathrm{ft}$. thick exists with more of a Christopher appearance. The Isachsen usually consists primarily of porous, quartzose sandstone, sands, and interbedded carbonaceous shales and coals. Often it is difficult to distinguish from consolidated portions of the Tertiary age Eureka Sound sandstones. Similarly, a transition from Christopher shale to Hassel sandstone is often characterised by a gradual lithology change. In view of the still questionable stratigraphy, and the seeming dominance of $S$. lunaris in Christopher sediments, an Albian age appears justifiable. Certainly our Arctic studies have indicated no wider range than AptianAlbian.

Manuscript received August 1987

Revised manuscript accepted February 1988

\section{REFERENCES}

Archangelsky, S. \& Gamerro, J. C. 1967. Spore and pollen types of Lower Cretaceous in Patagonia (Argentina). Rev. Palaeobotan. Palynol., Amsterdam, 1, 211-217 pls. 1-2.

Birkelund, T., Thusu, B. \& Vigran, J. 1978. JurassicCretaceous biostratigraphy of Norway, with comments on the British Rasenia Cymodoce zone. Palaeontology, London, 21, 31-63, pls. 1-6.

Bityuskaya, P. I. Bryzgalova, E. G. Budrin, V. S., Verbistskaya, Z. I. \& Markevick, V. S. 1973. Significance of the palynological method for the subdivision of the Cretaceous deposits of the North-Western part of the Pacific biogeographical area. In Boystove, E.P. (Ed.), Palynological method in Stratigraphy. Tr. Vses. Nauchn. Issled. Geologorazved. Inst. Nov. Ser., Lenningrad, 195, 73-121, pls. 1-19. In Russian.

Brideaux, W. W. \& McIntyre, D. J. 1975. Miospores and microplankton from Aptian-Albian rocks along Horton River, District of Mackenzie. Geol. Surv. Canada Bull., 252, 21-85, pls. 1-14.

Burger, D. 1973. Spore zonation and sedimentary history of the Neocomian, Great Artesian Basin, Queensland. In Glover, J. E. \& Playford, G. (Eds.), Mesozoic and Cainozoic Palynology: Essays in Honour of Isabel Cookson. Spec. Geol. Soc. Aust., 4, 87-118, pls. 1-2.

Burger, D. 1975. Cenomanian spores and pollen grains from Bathurst Island. In Norvick \& Burger, D, Palynology of the Cenomanian of Bathurst Island, Northern Territory, Australia. Bur. Miner. Resour. Aust. Bull. Canberra, 151, 169 pp., 34 pls.

Chlonova, A. F. 1961. Spores and pollen of the upper half of the upper Cretaceous in the eastern part of the western Siberian Lowland. T. Inst. Geol. Geofiz. Sibirsk, Otd. Akad, Nauk, SSSR, 7, 138 pp., 17 pls. In Russian.

Chlonova, A. F. 1969. Spore and pollen characteristic of Cretaceous deposits of Zeya-Biureya depression. In Charudo, I. (Ed.), Mesozoic spore and pollen assemblages of Siberia and Far East. Tr. Inst. Geol. Geofiz. Sibirsk. Ord. Akad. Nau. SSSR, Moscow, 91, 5-66. In Russian. 
Chlonova, A. F. 1971. Palynological characteristic of Cretaceous deposits of Siberia and Far East. In Sachs, V. N. (Ed.; Mesozoic microfossils of Siberia and far east $T r$. Inst. Geol. Geofi., Moscow, 138, pp. 52-151. In Russian.

Chlonova, A. F. 1974. Palynology of Cretaceous deposits of Siberia and Far East. Tr. Inst. Geol. Geofiz., Sibirsk. Otd. Akad. Nauk S.S.S.R., Novosibirsk, 96, 166 pp., pls. 1-6. In Russian.

Cookson, I. C. \& Dettmann, M. E. 1958. Some trilete spores from Upper Mesozoic Deposits in the eastern Australian region. Proc. Roy. Soc. Victoria, Melbourne, 70, 95-128, pls. $14-19$.

Dettmann, M. E. 1963. Upper Mesozoic microfloras from southeastern Australia. Proc. Roy. Soc. Victoria, Melbourne, 77, 1-148, pls. 1-27.

Doerenkamp, A., Jardine, S. \& Moreau, P. 1976. Cretaceous and Tertiary palynomorph assemblages from Banks Island and adjacent areas (N.W.T.) Bull Canadian Petrol. Geol., 24, 372-417.

Herngreen, G. F. W. \& Chlonova, A. F. 1981. Cretaceous microfloral provinces. Pollen et Spores., Paris, 23, 443 -555 , pls. $1-14$.

Hopkins, W. S. 1971. Palynology of the Lower Cretaceous Isachsen Formation on Melville Island, District of Franklin. Geol. Surv. Can. Bull., 197, 109-133, pls. 20-22.

Hopkins, W. S. 1974. Some spores and pollen from the Christopher formation (Albian) of Ellef and Amund Ringnes Island, and northwestern Melville Island, Canadian Arctic Archipelago. Geol. Surv. Can., Paper $72-12$, 39 pp., 6 pls.

Hopkins, W. S. \& Balkwill, H. R. 1973. Description, Palynology and Paleoecology of the Hassel Formation (Cretaceous) on eastern Ellef Ringnes Island, District of Franklin. Geol. Surv. Can., Paper $72-37,31$ pp. 2 pls.

Hopkins, W. S. \& Sweet, A. R. 1976. Miospores and megaspores from the Lower Cretaceous Mattagami Formation of Ontario. Geol. Surv. Can. Bull., 256, 55-71, pls. 9-12.

Kemp, E. M. 1970. Aptian and Albian miospores from southern England. Palaeontographics, Stuttgart, 131, 73 -143 , pls. $10-29$.

Kemp, E. M. 1976, Palynological observations in the Officer Basin, Western Australia. Bur. Mines. Resour. Aust. Bull. Canberra, 160, 23-39, pls. 1-2.

Kemp, E. M. \& Harris, W. K. 1977. The Palynology of early Tertiary sediments Ninetyeast Ridge Indian Ocean. Special Paper in Palaeontology, No. 19, London, 69 pp., 8 pls.

Komarova, N. I. 1973. Cretaceous miospore complexes of the Turgaj plain and Priaralje. In Palynological Method in Stratigraphy. Tr. Vses. Nauchn. Issled. Geologorazved. Inst. Nov. Ser., Leningrad 195, 122-134. In Russian.

Krutzsch, W. 1959. Mikropaläontologische (sporenpaläontologische) Untersuchungen in der Braunkohle des Geiseltales. Geologie, 8 (Beih. 21/22), 425 pp., 49 pls.

Kuyl, O. S., Muller, J. \& Waterbolk. H. Th. 1955. The application of palynology to oil geology with reference to Western Venezuala. Geologio in Minjnbouw. 17, 49-76, pls. $1-8$.

Muller, J. 1959. Palynology of Recent Orinoco delta and shelf sediments: Reports of the Orinoco Shelf Expedition; Volume 5. Micropaleontology, New York, 5, 1-32, pl. 1.
Plauchut, B. P. 1971. Geology of the Sverdrup Basin. Geol. Surv. Can. Bull., 19, 659-679.

Plauchut, B. P. \& Jutard, G. G. 1976. Cretaceous and Tertiary stratigraphy, Banks and Eglinton Islands and Anderson Plain (N.W.T.). Bull Canadian Petrol. Geol., 24, 321-371.

Playford, G. 1971. Palynology of lower Cretaceous (Swan River) strata of Saskatchewan and Manitoba. Palaeontology, London, 14, 553-565, pls. 103-107.

Potonié, R. 1956. Synopsis der Gattungen der Sporae dispersae. I Teil: Sporites. Beih. Geol. Jahrb., Hannover, 23, 103 pp., 11 pls.

Potonié, R. 1958. Synopsis der Gattungen der Sporae dispersae. II Teil: Sporites (Nachtrage), Saccites, Aletes, Praecoplates, Polyplicates, Monocolpates. Beih. Geol. Jahrb., Hannover, 31, 114 pp. 11 pls.

Robbins, E. I., Perry, W. J. \& Doyle, J. A. 1975. Palynological and stratigraphic investigations of four deep wells in the Salisbury Embayment of the Atlantic Coastal Plain. USGS Open File Rpt., No. 75-307, 120 pp., 5 figs.

Selling, O. H. 1946. Studies in Hawaiian pollen statistics. Part 1. The spores of the Hawaiian pteridophytes. 87 pp., 7 pls. Bishop Museum, Honolulu, Hawaii.

Shakhmoundes, V. A., 1971. A palynological evidence for the stratigraphical subdivision of the Hauterivian deposits of the Caspian Lowland In Samilovich, S. R. (Ed.), Palynology in Petroleum Geology. VNIGRI, Leningrad, 296, 144-169. In Russian.

Souaya, F. J. 1976. Foraminifera of Sun-Gulf-Global Linckens Island Well P-46, Arctic Archipelago, Canada. Micropaleontology, New York, 22, 249-306, pls. 1-12.

Stover, L. E. \& Evans, R. 1973. Upper Cretaceous-Eocene spore-pollen zonation offshore Gippsland Basin, Australia In Glover, J. E. \& Playford, G. (Eds.), Mesozoic and Cainozoic Palynology: Essays in Honour of Isabel Cookson Geol. Soc. Australia Special Publ. No. 4, 55-72, pls. 1-4.

Thusu, B. \& Vigran, J. O. 1976. A review of the palynolostratigraphy of the Jurassic system in Norway. Norwegian research council, Continental shelf, Publ. 67, 1-12.

Vigran, J. O. \& Thusu, B. 1975. Illustrations of Norwegian microfossils - Illustrations and distribution of the Jurassic palynomorphs of Norway. Norwegian Research Council, 65,55 pp., 20 pls. 